\title{
INGESTIVE BEHAVIOR AND FORAGE INTAKE OF HEIFERS RECEIVING CORN GRAIN WITH OR WITHOUT CRUDE GLYCERIN ON ITALIAN RYEGRASS PASTURE
}

\author{
COMPORTAMENTO INGESTIVO E INGESTÃO DE FORRAGEM POR BEZERRAS \\ RECEBENDO GRÃO DE MILHO COM OU SEM GLICERINA BRUTA EM \\ PASTAGEM DE AZEVÉM
}

\begin{abstract}
Guilherme Pegoraro GAI ${ }^{1}$; Luciana PÖTTER ${ }^{2}$; Marta Gomes da ROCHA ${ }^{2}$; Maria José de Oliveira SICHONANY ${ }^{3}$; Paulo Roberto SALVADOR ${ }^{4}$; Luiz Gonzaga do AMARAL NETO ${ }^{4}$; Érica Dambros de MOURA ${ }^{5}$; Lucas Munareto CADÓ ${ }^{6}$

1. Zootecnista, Mestre, Egresso do Programa de Pós Graduação em Zootecnia, Universidade Federal de Santa Maria - UFSM, Santa Maria, RS, Brasil; 2. Professora, Doutora, Programa de Pós Graduação em Zootecnia- UFSM, Santa Maria, RS, Brasil. potter.luciana@gmail.com; 3. Zootecnista, Mestre, Doutora, Egressa do Programa de Pós Graduação em Zootecnia- UFSM, Santa Maria, RS, Brasil; 4. Zootecnista, Mestre, Doutorando, Programa de Pós Graduação em Zootecnia, - UFSM, Santa Maria, RS, Brasil; 5. Zootecnista, Mestre, Egressa do Programa de Pós Graduação em Zootecnia da Universidade Federal do Rio Grande do Sul, Porto Alegre, RS, Brasil; 6. Zootecnista, Mestre, Doutorando, Programa de Pós Graduação em Zootecnia da Universidade Federal do Rio Grande do Sul, Porto Alegre, RS, Brasil.
\end{abstract}

\begin{abstract}
The objective was to analyze the ingestive behavior, forage intake and pasture characteristics when beef heifers are kept exclusively on ryegrass pasture (Lolium multiflorum Lam.) or receiving ground corn grain as supplement $(0.9 \%$ of body weight $(\mathrm{BW}))$ with or without addition of crude glycerin $(0.2 \% \mathrm{BW})$. Experimental animals were Angus heifers with initial age and body weight of eight months and $166.2 \pm 9.5 \mathrm{~kg}$, respectively. The grazing method was continuous with variable number of animals. The experimental design was completely randomized with repeated measures. Dry matter intake was estimated using chromium oxide as an indicator of fecal output. Heifers ingested a similar amount of dry matter and neutral detergent fiber. Forage intake was $19.0 \%$ lower when heifers receiving ground corn grain as supplement with or without addition of crude glycerin and these reduction in dry matter intake of forage provided increase of $38.2 \%$ in the stocking rate. Heifers that received crude glycerin as a supplement spent more time in the trough than heifers that received only ground corn grain.
\end{abstract}

KEYWORDS: Angus. Lolium multiflorum Lam. energy supplement. nutrients intake

\section{INTRODUCTION}

Grazing is a complex process performed by herbivorous to obtain forage to meet their nutritional requirements. Voluntary forage intake is the major factor influencing the productivity of pasture production systems and is influenced by characteristics related to the animal, the plant, the supplement, the environment and the pasture management (MERTENS, 1994).

Several factors determine the relationship between defoliation and characteristics of the grazing environment. The forage plant structure can have a striking influence on the decisions taken by the grazing animal as to searching and handling forage and the bite size throughout the day (PALHANO et al., 2002).

Some of the main effects of using supplements combined with high quality pasture, like ryegrass, are observed mainly in forage intake and ingestive behavior of grazing animals. Rosa et al. (2013) reported reduction in forage intake of 0.27 $\mathrm{kg}$ DM pasture for each $\mathrm{kg}$ DM corn grain ingested.
The reduction in forage intake by animals receiving supplement enables a greater selectivity of pasture and therefore intake of better quality forage (ADAMS, 1985).

Corn is a cereal standing out among the most used energy concentrates for cattle grazing in the State of Rio Grande do Sul, providing $0.968 \mathrm{~kg}$ day $^{-1}$ gain (SANTOS et al., 2005). The gain on marketable product may not always be accompanied by increases in the profitability of the activity based on the additional costs (ROSA et al., 2010). Thus, various types of byproducts are being tested in animal feed to replace or be combined with supplement ingredients to reduce the production cost.

Increasing biodiesel production increases the availability of glycerin, a byproduct that can be used in cattle feed. Crude glycerin can be included in the diet for ruminants as an energy ingredient. As any byproduct, however, it presents variations in quality, and may contain varying levels of glycerol in its composition (SANTANA JUNIOR et al., 2013). 
Dry matter intake plays an important role in the response of grazing ruminants, because it is influenced by diverse factors associated with the animal, the pasture, the environment and their interactions (CARVALHO et al., 2007). Ryegrass is the most widely cultivated winter grass in the State of Rio Grande do Sul, but there is still little known about the use of crude glycerin as a supplement in this pasture (PELLEGRIN et al., 2012), which justifies further studies on this topic. In this context, this study was undertaken to provided information on the ingestive behavior, forage intake and pasture and grazing characteristics when beef heifers are kept exclusively on ryegrass pasture (Lolium multiflorum Lam.) or receiving ground corn grain as a supplement $(0.9 \%$ body weight $(\mathrm{BW}))$ with or without addition of crude glycerin $(0.2 \% \mathrm{BW})$.

\section{MATERIAL AND METHODS}

This experiment was approved by the Ethics Committee for animal experimentation of Universidade Federal de Santa Maria (protocol 035/2013). This study was carried out at the Federal University of Santa Maria (UFSM), located in the Central Depression of the State of Rio Grande do Sul, Brazil. The climate in the region is humid subtropical, according to the Köppen classification. A total of 27 Angus heifers, eight months old and average body weight $166.2 \pm 9.5 \mathrm{~kg}$ were used. Feeding systems consisted of heifers exclusively on Italian ryegrass pasture (Lolium multiflorum Lam.) or receiving $0.9 \%$ of body weight (BW) of ground corn grain with or without addition of $0.2 \% \mathrm{BW}$ crude glycerin.

Ryegrass pasture was sown in May 2012 in an experimental area of 7.2 hectares with nine paddocks of similar size. We used $45 \mathrm{~kg} \mathrm{ha}^{-1}$ seeds and $250 \mathrm{~kg} \mathrm{ha}^{-1}$ NPK fertilizer (5-20-20). Top dressing fertilization was performed with $84.4 \mathrm{~kg}$ $\mathrm{ha}^{-1}$ nitrogen $(\mathrm{N})$ as urea, in three applications. The first application was made after the emergence of the second tiller of ryegrass and the others at intervals of 30 days. Corn grain was composed of $88.9 \%$ dry matter (DM), $1.4 \%$ mineral matter $(\mathrm{MM}), 98.7 \%$ organic matter $(\mathrm{OM}), 21.8 \%$ neutral detergent fiber (NDF), $4.3 \%$ ether extract (EE), $8.5 \%$ crude protein $(\mathrm{CP})$ and $80.8 \% \mathrm{DM}$ in situ digestibility (DMISD). Crude glycerin was composed of $82.1 \% \mathrm{DM}, 4.3 \% \mathrm{MM}, 95.7 \% \mathrm{OM}$, $0.13 \% \mathrm{EE}, 0.0 \% \mathrm{CP}$ and $3833.8 \mathrm{Kcal} \mathrm{kg}^{-1}$ crude energy. The supplements were provided daily at 2:00 p.m.

The grazing method was put-and-take stocking to maintain $2.0 \mathrm{t} / \mathrm{ha} \mathrm{DM}$ forage mass and minimum canopy height of $10 \mathrm{~cm}$. Forage mass (FM; kg DM/ha) was evaluated every 14 days by direct visual estimation method with double sampling. Canopy height $(\mathrm{cm})$ was measured at the same time with a ruler, with 20 readings in each paddock. The forage was cut at the grounded level and the samples collected were split into two subsamples for determination of DM content and for manual separation of structural components of ryegrass. After botanical separation and drying of structural components in a forced air circulation oven at $55^{\circ} \mathrm{C}$ for 72 hours, we determined the percentage participation of leaf blades, stems, inflorescences and dead material. Next, we calculated the leaf: stem ratio (L:S). Tiller density was determined by counting the number of ryegrass tillers in three predetermined areas of the paddock with $0.0625 \mathrm{~m}^{2}$ each.

Animals were weighed every 28 days, following a 12-hour fast from solids and liquids. The stocking rate (SR; $\mathrm{kg} / \mathrm{ha}$ body weight) was calculated by measuring the sum of the mean body weight of test animals plus the average weight of animals used for adjustments in the stocking rate, multiplied by the number of days in the experimental unit, and divided by the number of days in the trial period. The forage accumulation rate (FAR; $\mathrm{kg} / \mathrm{ha} /$ day $\mathrm{DM}$ ) was determined by using three exclusion cages in each paddock. Forage allowance (FA; kg DM forage/kg body weight/day) was calculated by the equation: ((FM/number of days of the period) + FAR)/SR of the period*100.

Grazing was simulated according to the methodology described by Euclides et al. (1992). Forage samples from the grazing simulation were pre-dried at $55{ }^{\circ} \mathrm{C}$ for 72 hours and ground in a Wiley mill for later laboratory analysis. Ash content was determined by combustion at $600{ }^{\circ} \mathrm{C}$ for four hours and the organic matter $(\mathrm{OM})$ by mass difference. Total nitrogen $(\mathrm{N})$ was determined by the Kjeldahl method (Method 984.13, AOAC, 1997). Analysis of neutral detergent fiber (NDF) was performed according to Senger et al. (2008). Ether extract (EE) was determined in ether refluxing system (Soxtherm Gerhardt, Germany) at $180{ }^{\circ} \mathrm{C}$ for two hours. The organic matter in situ digestibility (OMISD) was determined by incubation for 48 hours in the rumen.

Forage intake was evaluated in the periods: $06 / 08$ to $02 / 09 / 2013,03 / 09$ to $30 / 09 / 2013,01 / 10$ to $10 / 28 / 2013$ to coincide with other assessments for pasture and animal. Chromium oxide $\left(\mathrm{Cr}_{2} \mathrm{O}_{3}\right)$ was used as an indicator of fecal output, with supply period of eleven days and collection of feces from the eighth day (12:00 p.m. and 12:00 a.m., 3:00 p.m. 
and 03:00 a.m., 6:00 p.m. and 06:00 a.m., 9:00 p.m. and 09:00 a.m.). Chromium levels in dried feces were determined by atomic absorption spectrophotometry for technique adapted by Kozloski et al. (1998). Fecal output was estimated by the formula: $\mathrm{FO}=$ chromium supplied $(\mathrm{g}$ day $\left.{ }^{1}\right) /$ chromium in the feces $\left(\mathrm{g} \mathrm{kg}^{-1} \mathrm{DM}\right.$ ) (Pond et al., 1989). Forage intake was evaluated (FI, kg day ${ }^{-1}$ DM) by the formula: FI = fecal output - (IDM supplement $*(1 \quad$-supplement digestibility)) (1forage digestibility) -1 . From these data, the total intake, forage intake, NDF intake and $\mathrm{CP}$ intake were calculated, as \% BW. The substitution coefficient (reduction in DM forage intake per $\mathrm{kg}$ DM supplement intake) was estimated according to Hodgson (1990).

For ingestive behavior evaluation, test animals were observed for 24 uninterrupted hours in each experimental period. In 10-minute intervals, the grazing, rumination and other activities total time were evaluated (Jamieson and Hodgson, 1979). Also, the daily bites rate data were recorded, measured by the time spent by the animal to make 20 bites (FORBES; HODGSON, 1985). By dividing the estimated forage intake in the days of evaluation of feeding behavior (g DM) by the number of bites, the estimated mass was obtained for each bite in $\mathrm{g}$ DM/bite (FORBES, 1988).

A completely randomized design with repeated measurement arrangement was used, three feeding systems and three replications of area for treatments. For evaluation of ingestive behavior and forage intake, animals were considered replicates.

Statistical analyses were performed using the 'Mixed' procedure of SAS software for variables that showed normality of residuals. We performed a structure selection test using the Bayesian information criterion (BIC) to determine the model that best represented the data. We used a mixed model with fixed effects (feeding systems, periods of assessment and their interactions) and random effects (the residual and the nested paddocks in each feeding system). The interaction between feeding systems and evaluation periods was significant at $5 \%$ probability. Whenever significant differences were detected, mean values were compared using the lsmeans test. We used a stepwise procedure in multiple regression analysis to identify the most influential independent variables. From the equations obtained, we selected the one with the lowest P-value, residual variance and number of independent variables, and the highest coefficient of determination. The variables canopy height, CP intake, CP forage intake were transformed by rannor.

\section{RESULTS AND DISCUSSION}

There was no interaction $(\mathrm{P}>0.05)$ between feeding systems $\times$ evaluation periods for the variables related to pasture. Heifers, in the different feeding systems, were kept on similar forage mass $\left(\mathrm{FM} ; 2260.0 \pm 149.5 \mathrm{~kg} \mathrm{ha}^{-1} \mathrm{DM}\right)$, canopy height $(\mathrm{CH} ; 13.6 \pm 0.7 \mathrm{~cm})$, tiller population density (TPD, $4527.5 \pm 554.2$ tillers $\mathrm{m}^{21}$ ), leaf:stem ratio (LSR, 1.6 \pm 0.2 ), forage allowance $(\mathrm{FA} ; 12.7 \pm 0.5 \% \mathrm{BW})$, leaf blades allowance (LBA, $4.0 \pm 0.5 \% \mathrm{BW}$ ), neutral detergent fiber (NDF; $51.9 \pm 1.2 \%$ ), crude protein $(\mathrm{CP} ; 20.8 \pm 0.8 \%)$ and dry matter in situ digestibility (DMID; $79.3 \pm 1.9 \%)$. These variables showed differences between the periods of evaluation of ryegrass $(\mathrm{P}<0.05$; Table 1$)$.

The forage mass range required for the adequate performance of animals on ryegrass pasture is between 1100 and $1800 \mathrm{~kg} \mathrm{ha}^{-1} \mathrm{DM}$ (Roman et al., 2007) and canopy height must be between 10 and $15 \mathrm{~cm}$ to optimize the biomass flow (Pontes et al., 2004). Due to the high tiller population density, which led to a greater forage mass (Table 1) than that reported by Roman et al. (2007), it was recommend to keep the canopy height in the range $10-15 \mathrm{~cm}$, for no limitation on forage intake by animals.

The forage and leaf blades allowance were close to values obtained by Eloy et al. (2014) of $9.7 \% \mathrm{BW}$ and $4.3 \% \mathrm{BW}$, respectively, on ryegrass pasture, not limiting forage intake by heifers. Forage allowance was 3.2 times higher than the value estimated by the National Research Council (NRC, 2000; $3.0 \%$ ) characterizing no limitation of intake (GIBB; TREACHER, 1976). The crude protein content in the apparently consumed forage showed a value $39 \%$ higher than recommended by the National Research Council (NRC, 2000), providing an average daily weight gain of $971.0 \mathrm{~g} \mathrm{day}^{-1}$ for heifers exclusively on ryegrass pasture and $1243.0 \mathrm{~g}$ $\mathrm{day}^{-1}$ for supplemented heifers. Even at the final third of usage, after 84 grazing days, heifers harvested forage with non-limiting CP content $(15.0 \%)$ for the category.

Heifers harvested forage with similar DMID in all feeding systems, with values similar to those obtained by Eloy et al. (2014) who reported average value of $79.2 \%$. Along the evaluation period, there was a reduction in DMID of the apparently consumed forage by heifers, with reductions of 10.5 and $29.2 \%$ in the second and third periods, respectively. The DMID was associated with the leaf:stem ratio of the ryegrass forage mass $(r=0.71$; $\mathrm{P}<0.0001)$ and the leaf blades allowance $(\mathrm{r}=0.82$; $\mathrm{P}<0.0001)$ reflecting the harvest of plant structures 
with higher amount of structural components along

the ryegrass cycle.

Table 1.Pasture characteristics and nutritive value of forage as grazed in the evaluation periods of Italian Ryegrass

\begin{tabular}{|c|c|c|c|c|c|}
\hline \multirow[b]{2}{*}{ Variables } & \multicolumn{2}{|c|}{ Periods } & \multirow[b]{2}{*}{$\begin{array}{l}10 / 01- \\
10 / 28\end{array}$} & \multirow[b]{2}{*}{$\mathrm{P}^{1}$} & \multirow[b]{2}{*}{$\mathrm{CV}^{2}$} \\
\hline & $\begin{array}{l}08 / 06- \\
09 / 02\end{array}$ & 09/03-09/30 & & & \\
\hline Forage mass $^{3}$ & $1725.2 \mathrm{c}$ & $2257.2 \mathrm{~b}$ & $2797.8 \mathrm{a}$ & $<0.0001$ & 4.4 \\
\hline Canopy height ${ }^{4}$ & 10.1 & 12.3 & 18.5 & 0.0618 & 5.8 \\
\hline $\begin{array}{l}\text { Tiller } \\
\text { density }^{5}\end{array}$ population & $4096.6 \mathrm{~b}$ & $5414.5 \mathrm{a}$ & $4071.4 \mathrm{c}$ & $<0.0001$ & 9.0 \\
\hline Leaf:stem ratio & $3.1 \mathrm{a}$ & $1.3 \mathrm{~b}$ & $0.5 \mathrm{c}$ & $<0.0001$ & 18.9 \\
\hline Forage allowance $^{6}$ & 11.8 & 12.9 & 13.4 & 0.4226 & 6.8 \\
\hline $\begin{array}{ll}\text { Leaf } & \text { blades } \\
\text { allowance }^{7} & \end{array}$ & $5.5 \mathrm{a}$ & $5.0 \mathrm{a}$ & $1.3 \mathrm{~b}$ & $<0.0001$ & 15.8 \\
\hline Dry matter $^{8}$ & $18.1 \mathrm{c}$ & $20.5 b$ & $28.1 \mathrm{a}$ & $<0.0001$ & 2.4 \\
\hline $\begin{array}{l}\text { Neutral detergent } \\
\text { fiber }^{8}\end{array}$ & $44.9 \mathrm{c}$ & $50.4 \mathrm{~b}$ & $60.3 \mathrm{a}$ & $<0.0001$ & 2.2 \\
\hline Crude protein ${ }^{8}$ & $24.9 \mathrm{a}$ & $22.5 b$ & $15.0 \mathrm{c}$ & $<0.0001$ & 3.6 \\
\hline DMID $^{8,9}$ & $91.3 \mathrm{a}$ & $82.6 \mathrm{~b}$ & $63.9 \mathrm{c}$ & $<0.0001$ & 2.5 \\
\hline
\end{tabular}

${ }^{1}$ Probability of evaluation periods; ${ }^{2}$ Coefficient of variation (\%); ${ }^{3} \mathrm{~kg} \mathrm{ha}^{-1}$ of DM; ${ }^{4} \mathrm{~cm} ;{ }^{5}$ Tillers $\mathrm{m}^{-1} ;{ }^{6} \mathrm{~kg}$ of DM $100 \mathrm{~kg}^{-1}$ of BW; ${ }^{7} \mathrm{~kg}$ of leaf blades $100 \mathrm{~kg}^{-1}$ of BW; ${ }^{8} \%$; ${ }^{9} \mathrm{DMID}=$ dry matter in situ digestibility. Values followed by different letters in the same line differs by lsmeans procedure

Moreover, there was no interaction $(\mathrm{P}>0.05)$ between feeding systems $\times$ evaluation periods for the variables related to intake. Heifers, in the different feeding systems, showed similar total consumption $(3.2 \pm 0.1 \% \mathrm{BW})$, total NDF intake $(1.3 \pm 0.1 \% \mathrm{BW})$, forage $\mathrm{CP}$ intake $(0.5 \pm 0.04 \%$ $\mathrm{BW})$ and total CP intake $(0.6 \pm 0.04 \% \mathrm{BW})$. These variables showed differences between the periods of evaluation of ryegrass $(\mathrm{P}<0.05$; Table 2$)$.

Forage intake by heifers differed between feeding systems $(\mathrm{P}<0.05)$. Animals exclusively on pasture ingested $19.0 \%$ more forage compared to heifers fed corn grain with or without addition of crude glycerin (Table 2). Thus, the reduction in forage intake by supplemented animals was compensated by the intake of supplement, so that the total intake of DM was similar. The rate of replacement of DM of the forage with DM from the supplement was 0.58 for corn grain with or without addition of crude glycerin. Given the reduction in forage intake to maintain the same forage mass in all feeding systems, there was a $38.2 \%$ increase in stocking rate in relation to the exclusive use of pasture (847.2 $\left.\pm 0.1 \mathrm{~kg} \mathrm{ha}^{-1} \mathrm{BW} ; \mathrm{P}<0.05\right)$.

The forage NDF intake by heifers also differed between feeding systems $(\mathrm{P}<0.05)$. The higher intake of forage NDF was found for heifers exclusively on pasture without difference from heifers fed corn, which, in turn, showed no differences from heifers fed corn with added glycerin (Table 2). As heifers consume greater amount of forage when exclusively on pasture and NDF content of the apparently consumed forage is similar in all feeding systems, the heifers exclusively on ryegrass consumed greater amounts of neutral detergent fiber.

Heifers that received corn grain have showed lower forage intake than animals exclusively on pasture. Corn grain presented NDF content of $21.8 \%$, which provided a NDF intake similar to those of heifers on ryegrass pasture, receiving or not corn grain. In turn, heifers fed corn grain with added crude glycerin, besides having lower intake of forage, received a supplement able to provide temporary satiation and thus consumed less forage and consequently less NDF.

Additionally, there was interaction $(\mathrm{P}<0.05)$ between feeding systems $\times$ evaluation periods for grazing time (Table 3). In the first period, the heifers exclusively grazing on ryegrass remained 207.4 minutes $(65.7 \%)$ more than heifers receiving corn grain with added glycerin, which spent 315.8 minutes grazing. Animals that received corn grain remained grazing an intermediate time compared to heifers in the other feeding systems. This reduction in the grazing time shows that the supplemented animals require less time to ingest the same amount of DM than the heifers of the feeding system exclusively on pasture (Table 3 ). 
Table 2. Forage intake, total intake, neutral detergent fiber intake of forage and total neutral detergent fiber intake by beef heifers exclusively in Italian Ryegrass or receiving grain with or without crude glycerin

\begin{tabular}{|c|c|c|c|c|c|}
\hline \multirow[b]{2}{*}{ Feeding systems } & \multicolumn{3}{|c|}{ Periods } & \multirow[b]{2}{*}{ Average } & \multirow[b]{2}{*}{$\mathrm{P}^{*}$} \\
\hline & $\begin{array}{l}08 / 06- \\
09 / 02\end{array}$ & $\begin{array}{l}09 / 03- \\
09 / 30\end{array}$ & $\begin{array}{l}10 / 01- \\
10 / 28\end{array}$ & & \\
\hline \multicolumn{6}{|c|}{ 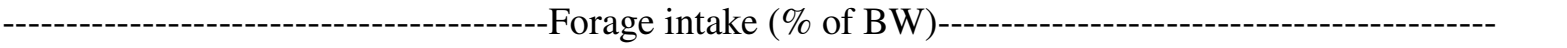 } \\
\hline Ryegrass & 3.3 & 3.1 & 2.4 & $2.9 \pm 0.1 \mathrm{a}$ & 0.0095 \\
\hline Corn & 3.0 & 2.4 & 2.0 & $2.5 \pm 0.1 \mathrm{~b}$ & \\
\hline Glycerin & 2.8 & 2.0 & 2.0 & $2.2 \pm 0.1 b$ & \\
\hline \multirow{2}{*}{\multicolumn{5}{|c|}{--Total intake (\% of BW)- }} & 0.0001 \\
\hline & & & & & 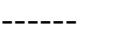 \\
\hline Ryegrass & 3.3 & 3.1 & 2.4 & $2.9 \pm 0.1$ & 0.0858 \\
\hline Corn & 3.9 & 3.3 & 2.9 & $3.4 \pm 0.1$ & \\
\hline Glycerin & 3.9 & 3.1 & 3.1 & $3.3 \pm 0.1$ & \\
\hline Average & $3.7 \pm 0.1 \mathrm{a}$ & $3.2 \pm 0.1 b$ & \multicolumn{2}{|l|}{$2.8 \pm 0.1 \mathrm{c}$} & 0.0001 \\
\hline \multicolumn{6}{|c|}{----Neutral detergent fiber intake of forage $(\%$ of $\mathrm{BW})$} \\
\hline Ryegrass & 1.2 & 1.41 & 1.3 & $1.3 \pm 0.1 \mathrm{a}$ & 0.0398 \\
\hline Corn & 1.1 & 1.1 & 1.3 & $1.1 \pm 0.1 \mathrm{ab}$ & \\
\hline Glycerin & 0.9 & 0.9 & 1.2 & $1.0 \pm 0.1 b$ & \\
\hline Average & $1.0 \pm 0.1$ & $1.1 \pm 0.1$ & $1.3 \pm 0.1$ & & 0.0616 \\
\hline \multicolumn{5}{|c|}{ Total neutral detergent fiber intake (\% of BW)-----. } & ----- \\
\hline Ryegrass & 1.2 & 1.4 & 1.3 & $1.3 \pm 0.1$ & 0.4629 \\
\hline Corn & 1.2 & 1.2 & 1.5 & $1.3 \pm 0.1$ & \\
\hline Glycerin & 1.1 & 1.1 & 1.4 & $1.2 \pm 0.1$ & \\
\hline Average & $1.1 \pm 0.1 \mathrm{~b}$ & $1.2 \pm 0.1 \mathrm{ab}$ & $1.4 \pm 0.1 \mathrm{a}$ & & 0.0325 \\
\hline
\end{tabular}

Values followed by different letters in the same line or column differs by lsmeans procedure; *Probability; Ryegrass=heifers on Italian Ryegrass; Corn=heifers on Italian Ryegrass $+0.9 \%$ of BW of ground corn grain; Glycerin= heifers on Italian Ryegrass $+0.9 \%$ of BW of ground corn grain with addition of crude glycerin

Table 3. Components of ingestive behavior of beef heifers exclusively on Italian Ryegrass pasture or receiving grain with or without crude glycerin as supplement

\begin{tabular}{|c|c|c|c|c|c|}
\hline \multirow[b]{2}{*}{ Feeding systems } & \multicolumn{3}{|c|}{ Periods } & \multirow[b]{2}{*}{ Average } & \multirow[b]{2}{*}{$\mathrm{P}^{*}$} \\
\hline & $\begin{array}{l}08 / 06- \\
09 / 02\end{array}$ & $\begin{array}{l}09 / 03- \\
09 / 30\end{array}$ & $\begin{array}{l}10 / 01- \\
10 / 28\end{array}$ & & \\
\hline Ryegrass & $523.3 \mathrm{a}$ & $443.0 \mathrm{a}$ & $444.7 \mathrm{a}$ & $470.3 \pm 16$ & 0.0003 \\
\hline Corn & $419.0 \mathrm{~b}$ & $390.1 \mathrm{a}$ & $389.9 a$ & $399.7 \pm 16$ & \\
\hline Glycerin & $315.8 \mathrm{c}$ & $380.9 a$ & $430.9 a$ & $375.9 \pm 16$ & \\
\hline Average & $419.4 \pm 16$ & $404.7 \pm 16$ & $421.8 \pm 16$ & & 0.7179 \\
\hline Azevém & 281.1 & 320.1 & 434.3 & $345.2 \pm 18$ & 0.2497 \\
\hline Milho & 277.7 & 272.2 & 359.0 & $334.1 \pm 18$ & \\
\hline Glicerina & 285.1 & 320.5 & 396.8 & $303.0 \pm 18$ & \\
\hline Média & $281.3 \pm 18 \mathrm{c}$ & $304.3 \pm 18 b$ & $396.7 \pm 18 a$ & & $<0.0001$ \\
\hline Ryegrass & 635.7 & $\begin{array}{l}\text { ther activities } \\
679.1\end{array}$ & $\begin{array}{l}(\min .) \\
560.9\end{array}$ & $625.2+22 b$ & 0.0350 \\
\hline Corn & 710.9 & 750.9 & 654.5 & $705.4 \pm 22 \mathrm{a}$ & \\
\hline Glycerin & 787.2 & 694.9 & 579.6 & $687.2 \pm 22 \mathrm{ab}$ & \\
\hline Average & $711.3 \pm 22 \mathrm{a}$ & $708.3 \pm 22 \mathrm{a}$ & $598.3 \pm 22 b$ & & 0.0006 \\
\hline & & --Trough time & ) ----------- & - & -- \\
\hline Ryegrass & . & & & & 0.0065 \\
\hline Corn & 33.4 & 22.3 & 34.4 & $30.0 \pm 3 b$ & \\
\hline Glycerin & 51.3 & 43.4 & 32.3 & $42.3 \pm 3 a$ & \\
\hline Average & $42.3 \pm 3$ & $32.9 \pm 3$ & $33.3 \pm 3$ & & 0.1408 \\
\hline
\end{tabular}


Heifers presented a similar grazing time in the second (404.7 min.) and third (421.8 min.) evaluation periods, independent of the feeding system. In these periods, there was a reduction in the leaf:stem ratio and DMID (Table 1) according to the ryegrass cycle, which probably were accounted for the reduction in the amount of forage consumed by the animals.

The grazing time of heifers exclusively on pasture depends on the forage allowance, according to the equation: $\hat{\mathrm{Y}}=789.8-94.3 \mathrm{FA}(\mathrm{P}=0.0718$; $\mathrm{r}^{2}=0.51$ ), demonstrating that the heifers exclusively on pasture reduced grazing in 94.3 minutes when the FA increased $1 \%$. The grazing time of heifers fed corn grain with added crude glycerin was explained by the leaf:stem ratio, according to the equation: $\hat{\mathrm{Y}}=439.3-47.6 \mathrm{LSR}\left(\mathrm{P}=0.0002 ; \mathrm{r}^{2}=0.89\right)$, in which heifers decreased 47.6 minutes of grazing when the LSR increased by 1 point. The addition of crude glycerin in the diets for heifers may probably have caused satiety, because, when ingested, glycerol (main component of crude glycerin) is converted into propionate in the rumen (TRABUE et al., 2007). The dynamics of satiety leads the animals to show reduction in instantaneous intake rate during grazing by means of a higher selectivity (GREGORINI et al., 2007), in other words, the greatest satiety leads the animals to be more selective during the grazing, seeking pastures with higher proportion of leaves. The grazing time of heifers on ryegrass pasture receiving corn grain as a supplement did not fit to any regression model.

There was no interaction $(\mathrm{P}>0.05)$ between feeding systems $\times$ evaluation periods for the variables rumination, other activities and trough time. Heifers in the different feeding systems showed a similar rumination time $(327.4 \pm 16.1$ minutes; $\mathrm{P}>0.05)$. This value is according to that verified by Bremm et al. (2005), when heifers ruminated 393.0 minutes on oat and ryegrass pastures. This result is explained by the similarity in total NDF intake by heifers, regardless of the feeding system, despite the differences in forage NDF content between evaluation periods (Table 1).

During the first and second evaluation periods, animals showed a shorter rumination time $(292.8 \pm 18.4 \mathrm{~min}$.) compared to the third period (396.7 $\pm 18.4 \mathrm{~min}$.$) . The rumination time was$ positively correlated with the NDF content in the apparently consumed forage $(\mathrm{r}=0.51 ; \mathrm{P}=0.007)$. The NDF content increased along the ryegrass cycle (Table 1), and the fiber fraction is the main factor stimulating chewing (GRANT; ALBRIGHT, 1995).

The different feeding systems interfered with the other activities and trough time
$(\mathrm{P}<0.05)$. Heifers that received corn grain remained more 80.2 minutes in other activities when compared to heifers exclusively on pasture. The heifers receiving corn grain with added glycerin remained a similar time in other activities than the other animals (Table 3). This behavior can be explained by the excluding nature of each of the activities. The animal cannot perform more than one activity at the same time, which could lead to competition between feeding activities in the distribution of time (FISCHER et al., 1998).

The time spent in other activities differed between evaluation periods $(\mathrm{P}<0.05)$. In the first and second periods, animals spent time in other activities $18.7 \%$ longer than in the third period $(598.3 \pm 22.4 \mathrm{~min}$.). This result may be related to the LBA, which was higher in the first and second periods $(5.3 \% \mathrm{BW})$ and lower in the third period $(1.3 \% \mathrm{BW})$, allowing a greater grazing selectivity and thus the harvest of a higher proportion of leaf blades, more rapidly. In this way, the stimulation to interrupt the meal associated with the possible increase in satiety signals is faster (BAGGIO et al., 2008).

Heifers supplemented with crude glycerin exhibited a longer time in the trough (min.) than those fed only corn grain as supplement $(\mathrm{P}<0.05)$. This is because the animals receiving crude glycerin did not have prior experience with this supplement (NEWMAN et al., 1992) and because the crude glycerin is viscous, which differs from corn grain, making it difficult the consumption of the supplement by heifers.

There was interaction between feeding systems $\times$ evaluation periods for bite rate $(\mathrm{P}<0.05$; Table 4). In the first and third (41.9 bites $\mathrm{min}^{-1}$ ) evaluation periods, the animals performed a similar bite rate, regardless of the feeding system. In the second period, the heifers exclusively on pasture and those that received corn grain performed more 7.6 bites per minute than those fed corn grain with added glycerin. Probably, the greater satiety caused by crude glycerin intake led the animals to perform fewer bites per minute during grazing. 
Table 4. Rate and bite mass of beef heifers kept exclusively on Italian Ryegrass or receiving corn grain with or without crude glycerin as supplement

\begin{tabular}{|c|c|c|c|c|c|}
\hline \multicolumn{6}{|c|}{ Periods } \\
\hline $\begin{array}{l}\text { Feeding } \\
\text { systems }\end{array}$ & $\begin{array}{l}\text { 08/06- } \\
09 / 02\end{array}$ & $\begin{array}{l}09 / 03- \\
09 / 30\end{array}$ & $\begin{array}{l}10 / 01- \\
10 / 28\end{array}$ & Average & $\mathrm{P}^{*}$ \\
\hline \multicolumn{6}{|c|}{--Bite rate (bite $\min ^{-1}$ ) --. } \\
\hline Ryegrass & $45.7 \mathrm{a}$ & $50.2^{\mathrm{a}}$ & $38.0 \mathrm{a}$ & $44.7 \pm 1.1$ & 0.0115 \\
\hline Corn & $50.6 \mathrm{a}$ & $45.9^{\mathrm{a}}$ & $36.5 \mathrm{a}$ & $44.4 \pm 1.1$ & \\
\hline Glycerin & $47.2 \mathrm{a}$ & $40.5 b$ & $33.7 \mathrm{a}$ & $40.5 \pm 1.1$ & \\
\hline Average & $47.8 \pm 1.1$ & $45.5 \pm 1.1$ & $36.1 \pm 1.1$ & & $<0.0001$ \\
\hline \multicolumn{6}{|c|}{---Bite mass $\left(\mathrm{g} \mathrm{bite}^{-1}\right)$------- } \\
\hline Ryegrass & 0.4 & 0.4 & 0.4 & $0.4 \pm 0.04$ & 0.9522 \\
\hline Corn & 0.4 & 0.4 & 0.5 & $0.4 \pm 0.04$ & \\
\hline Glycerin & 0.4 & 0.4 & 0.4 & $0.4 \pm 0.04$ & \\
\hline Average & $0.4 \pm 0.03$ & $0.4 \pm 0.03$ & $0.4 \pm 0.03$ & & 0.5371 \\
\hline
\end{tabular}

Values followed by different letters in the same line or column differs by lsmeans procedure; *Probability; Ryegrass=heifers on Italian Ryegrass; Corn=heifers on Italian Ryegrass $+0.9 \%$ of BW of ground corn grain; Glycerin $=$ heifers on Italian Ryegrass $+0.9 \%$ of BW of ground corn grain with addition of crude glycerin

The bite rate of heifers kept on ryegrass pasture and supplemented with corn grain was explained by in situ dry matter digestibility, according to the equation: $\hat{Y}=0.4+0.5$ DMID $\left(\mathrm{P}=0.0125 ; \mathrm{r}^{2}=0.61\right)$, where the $1 \%$ reduction in DMID made the heifers to reduce 0.5 bites minute ${ }^{-1}$. The bite rate of heifers receiving corn grain with addition of crude glycerin was explained by the neutral detergent fiber content, according to the equation: $\hat{\mathrm{Y}}=73.8-0.6 \mathrm{NDF}\left(\mathrm{P}=0.0176 ; \mathrm{r}^{2}=0.58\right)$, demonstrating that the $1 \%$ increase in the NDF content made the heifers to reduce 0.6 bites minute. Considering that the bite mass was constant throughout the evaluation period and that the heifers have reduced forage intake with advancing ryegrass cycle (Table 2), the bite rate also had to be reduced. The bite rate of heifers kept exclusively on ryegrass pasture did not fit to any regression model.

Finally, there was no interaction $(\mathrm{P}>0.05)$ between feeding systems $\times$ evaluation periods for the variable bite mass $\left(\mathrm{g} \mathrm{DM}\right.$ bite $\left.^{-1}\right)$. The bite mass was similar $\left(0.4 \pm 0.0 \mathrm{~g} \mathrm{DM}\right.$ bite $\left.^{-1} ; \mathrm{P}>0.05\right)$ for heifers in all feeding systems and evaluation periods. The bite mass is a major determinant of forage intake in grazing situation (LACA; ORTEGA, 1995). The value found herein is higher than the value considered limiting for the daily intake of 0.3g OM bite ${ }^{-1}$ reported by Stobbs (1973). Although the LSR, content of CP, NDF and DMISD have varied with advancing pasture cycle (Table 1), heifers were able to keep a constant bite mass throughout the utilization period of the pasture.

\section{CONCLUSIONS}

The addition of $0.2 \%$ of body weight of crude glycerin in the diet for beef heifers on Italian ryegrass pasture shows no effect on total intake or chemical composition of the apparently consumed forage.

The addition of crude glycerin to corn grain as a supplement in ryegrass pasture does not change the forage intake in relation to the exclusive use of corn grain. Forage intake is higher when the heifers remain exclusively on ryegrass.

The supply of ground corn grain, with or without addition of crude glycerin, for beef heifers on ryegrass increases the stocking rate.

The grazing time of heifers exclusively on ryegrass pasture is influenced by forage allowance, and when supplied corn with added crude glycerin, this is influenced by the leaf blades allowance.

RESUMO: Objetivou-se avalizar o comportamento ingestivo, ingestão de forragem e as características da pastagem quando bezerras de corte são mantidas exclusivamente em pastagem de azevém (Lolium multiflorum Lam.) ou recebendo grão de milho quebrado como suplemento $(0,9 \%$ do peso corporal (PC)) com ou sem adição de glicerina bruta (0,2\% PC). Os animais experimentais foram bezerras Angus com idade e peso inicial de oito meses e 166,2 $\pm 9,5 \mathrm{~kg}$, respectivamente. $\mathrm{O}$ método de pastejo foi o contínuo com número variável de animais. $\mathrm{O}$ delineamento experimental foi $\mathrm{o}$ inteiramente casualizado com medidas repetidas no tempo. A ingestão de matéria seca foi estimada usando óxido de cromo como indicador de produção fecal. As bezerras ingeriram similares quantidades de matéria seca e fibra em detergente neutro. A ingestão de forragem foi $19.0 \%$ menor quando as bezerras recebem grão de milho quebrado como suplemento com ou sem adição de glicerina bruta e essa redução na ingestão de matéria seca de forragem promove aumento de $38,2 \%$ 
na taxa de lotação. Bezerras que recebem glicerina bruta como suplemento permanecem mais tempo no cocho do que bezerras que recebem somente grão de milho quebrado.

PALAVRAS CHAVE: Angus. Lolium multiflorum Lam. Suplemento energético. Ingestão de nutrientes.

\section{REFERENCES}

ADAMS, D. C. Effect of time of supplementation on performance, forage intake and grazing behavior of yearling beef steers grazing Russian wild ryegrass in the fall. Journal of Animal Science, Champaign, v. 61, n. 5, p. 1037-1042, jun. 1985. https://doi.org/10.2527/jas1985.6151037x

ASSOCIATION OF OFFICIAL ANALYTICAL CHEMISTS. 1997. Official Methods of Analysis. $16^{\text {th }} .3$ nd ed. AOAC INTERNATIONAL. Gaithersburg. MD.

BAGGIO, C.; CARVALHO, P. C. F.; SILVA, J. L. S.; ROCHA, L. M. D.; BREMM, C.; SANTOS, D. T. D.; MONTEIRO, A. L. G. Padrões de uso do tempo por novilhos em pastagem consorciada de azevém-anual e aveia-preta. Revista Brasileira de Zootecnia, Viçosa, v. 37, n. 11, p. 1912-1918, nov. 2008.

BREMM, C.; ROCHA, M. G.; RESTLE, J.; PILAU, A.; MONTAGNER, D. B.; FREITAS, F. D.; MACARI, S.; ELEJALDE, D. A. G.; ROSO, D.; ROMAN, J.; GUTERRES, E. P.; DA COSTA, V. G.; NEVES, F. P. Efeito de níveis de suplementação sobre o comportamento ingestivo de bezerras de corte em pastagem de aveia (Avena strigosa Schreb.) e azevém ( Lolium multiflorum Lam.). Revista Brasileira de Zootecnia, Viçosa, v. 34, n. 2, p. 387-397, abr. 2005.

CARVALHO, P. C. F.; KOZLOSKI, G. V.; RIBEIRO FILHO, H. M. N.; REFFATTI, M. V.; GENRO, T. C. M.; EUCLIDES, V. P. B. Avanços metodológicos na determinação do consumo de ruminantes em pastejo.

Revista Brasileira de Zootecnia, Viçosa, v. 36, supl. p. 151-170, jul. 2007.

ELOY, L. R.; ROCHA, M. G.; PÖTTER L.; FONSECA NETO, A. M.; BISCAÍNO, L. L.; ALVES, M. B.; GRAMINHO, L. A.; STIVANIN, S. C. B. Consumo de forragem por novilhas de corte recebendo farelo de arroz integral com e sem ionóforo. Ciência Rural, Santa Maria, v. 44, n. 7, p. 1223-1228, jul. 2014. https://doi.org/10.1590/0103-8478cr20131135

EUCLIDES, V. P. B.; MACEDO, M. C. M.; OLIVEIRA, M. P. Avaliação de diferentes métodos de amostragem para estimar o valor nutritivo de forragens sob pastejo. Revista Brasileira de Zootecnia, Viçosa, v. 21, n. 4, p. 691-701, jul. 1992.

FISCHER, V.; DESWYSEN, A. G.; DESPRES, L.; DUTILLEUL, P; LOBATO, J. F. P. Padrões nictemerais do comportamento ingestivo de ovinos. Revista Brasileira de Zootecnia, Viçosa, v. 27, n. 2, p. 362-369, abr. 1998.

FORBES, T. D. A. Researching the plant-animal interface: The investigation of ingestive behaviour of cows and sheep. Journal of Animal Science, Champaign, v. 66, n. 9, p. 2369-2379, sep.1988.

https://doi.org/10.2527/jas1988.6692369x

FORBES, T. D. A.; HODGSON, J. Comparative studies of the influence of sward conditions on the behavior of cows and sheep. Grass and Forage Science, Oxford, v. 40, n. 1, p. 69-77, apr. 1985.

https://doi.org/10.1111/j.1365-2494.1985.tb01721.x

GIBB, M. J.; TREACHER, T. T. The effect of herbage allowance on herbage intake and performance of lambs grazing perennial ryegrass and red clover swards. Journal of Agricultural Science, Cambridge, v. 86, n. 2, p. 355-365, apr. 1976. https://doi.org/10.1017/S0021859600054824 
GRANT, R. J.; ALBRIGHT, J. L. Feeding Behavior and Management Factors During the Transition Period in Dairy Cattle. Journal of Animal Science, Champaign, v. 73, n. 9, p. 2791-2803, apr. 1995.

https://doi.org/10.2527/1995.7392791x

GREGORINI, P.; EIRIN, M.; WADE, M. H.; REFI, R.; URSINO, M.; ANSIN, O. E; GUNTER, S. A. The effects of a morning fasting on the evening grazing behavior and performance of strip-grazed beef heifers. The Professional Animal Scientist, v. 23, n. 6, p. 642-648, dec. 2007. https://doi.org/10.15232/S1080-

7446(15)31035-4

HODGSON. J. 1990. Grazing management: science into practice. London: Longman Scientific \& Technical. $203 p$.

JAMIESON, W. S.; HODGSON, J. The effect of daily herbage allowance and sward characteristics upon the ingestive behavior of calves under strip-grazing management. Grass and Forage Science, Oxford, v. 34, n. 4, p. 261-271, dec. 1979. https://doi.org/10.1111/j.1365-2494.1979.tb01478.x

KOZLOSKI, G. V.; FLORES, E. M. M.; MARTINS, A. F. Use of chromium oxide in digestibility studies: variations of the results as a function of the measurement method. Journal of the Science of Food and Agriculture, London, v. 76, n. 3, p. 373-376, mar. 1998. https://doi.org/10.1002/(SICI)1097-

0010(199803)76:3<373::AID-JSFA956>3.0.CO;2-Y

LACA, E. A.; ORTEGA, I. M. 1995. Integrating foraging mechanisms across spatial and temporal scales. International rangelands congress 5:129-132.

MERTENS, D. R. 1994 Regulation of forage intake. In: FAHEY Jr.. G. C. Forage quality, evaluation and utilization. Lincon: University of Nebraska. p. 450-493.

NATIONAL RESEARCH COUNCIL - NRC. 2000. Nutrient requeriments of beef cattle. Washington: National Academy. 249p.

NEWMAN, J. A.; PARSONS, A. J.; HARVEY, A. Not all sheep prefer clover: diet selection revisited. The Journal of Agricultural Science, Cambridge, v. 119, n. 2, p. 275-283, oct. 1992.

https://doi.org/10.1017/S0021859600014209

PALHANO, A. L.; CARVALHO, P. C. F.; BARRETO, M. Z. Influência da estrutura da pastagem na geometria do bocado e nos processos de procura e manipulação da forragem. Tuiuti: Ciência e Cultura, Curitiba, v. 31, n. 2, p. 33-52, jun. 2002.

PELLEGRIN, A. C. R. S.; PIRES, C. C.; CARVALHO, S.; PACHECO, P. S.; PELEGRINI, L. F. V.; GRIEBLER, L.; VENTURINI, R. S. Glicerina bruta no suplemento para cordeiros lactentes em pastejo de azevém. Ciência Rural, Santa Maria, v. 42, n. 8, p. 1477-1482, ago. 2012.

POND, K. R.; ELLIS, W. C.; MATIS, J. H.; DESWYSEN, A. G. Passage of chromium-mordanted and rare earthlabeled fiber: time of dosing kinetics. Journal of Animal Science, Champaign, v. 67, n. 4; p. 1020-1028, apr. 1989. https://doi.org/10.2527/jas1989.6741020x

PONTES, L.; CARVALHO, P. C. F.; NABINGER, C.; SOARES, A. B. Fluxo de biomassa em pastagem de azevém anual (Lolium multiflorum Lam.) manejada em diferentes alturas. Revista Brasileira de Zootecnia, Viçosa, v. 33, n. 3, p. 529-537, jun. 2004.

ROMAN, J.; ROCHA, M. G.; PIRES, C. C.; ELEJALDE, D. A. G.; KLOSS, M. G.; OLIVEIRA NETO, R. A. Comportamento ingestivo e desempenho de ovinos em pastagem de azevém anual (Lolium multiflorum Lam.) com diferentes massas de forragem. Revista Brasileira de Zootecnia, Viçosa, v. 36, n. 4, p. 780-788, ago. 2007. 
ROSA, A. T. N.; ROCHA, M. G.; PÖTTER, L.; KOSLOSKI, G. V.; ROSO, D.; OLIVEIRA NETO, R. A. Consumo de forragem e desempenho de novilhas de corte recebendo suplementos em pastagem de azevém. Ciência Rural, Santa Maria, v. 43, n. 1, p. 126-131, jan. 2013. https://doi.org/10.1590/S010384782013000100021

ROSA, A. T. N.; ROCHA, M. G.; PÖTTER, L.; ROSO, D.; COSTA, V. G.; RIBEIRO, L. A.; SICHONANY, M. J. O. Recria de bezerras de corte em pastagem de azevém sob frequências de suplementação. Ciência

Rural, Santa Maria, v. 40, n. 12, p. 2549-2554, dez. 2010. https://doi.org/10.1590/S0103-84782010001200018

SANTANA JUNIOR, H. A.; FIGUEIREDO, M. P.; SANTANA, E. O. C.; MENDES, F. B. L.; FILHO, G. A.; PINHEIRO, A. A.; LISBOA, M. M.; LUZ, Y. S.; VIANA, P. T.; FERREIRA, A. H. C.; RECH, C. L. S.

Glicerina bruta na dieta de vacas lactantes mantidas em pastagem tropical: comportamento ingestivo. Semina

Ciências Agrárias, Londrina, v. 34, n. 3, p. 1339-1352, jun. 2013. https://doi.org/10.5433/1679-

0359.2013v34n3p1339

https://doi.org/10.5433/1679-0359.2013v34n3p1339-1352

SANTOS, D. T.; ROCHA, M. G.; QUADROS, F. L. F.; GENRO, T. C. M.; GONÇALVES, E. N.; ROMAN, J. Suplementos energéticos para recria de novilhas de corte em pastagens anuais. Desempenho animal. Revista Brasileira de Zootecnia, Viçosa, v. 34, n. 1, p. 209-219, fev. 2005.

SENGER, C. C. D.; KOZLOSKI, G. V.; SANCHEZ, L. M. B.; MESQUITA, F. R.; ALVES, T. P.; CASTAGNINO, D. S. Evaluation of autoclave procedures for fibre analysis in forage and concentrate feedstuffs. Animal Feed Science and Technology, Amsterdam, v. 146, n. 2, p. 169-174, sep. 2008. https://doi.org/10.1016/j.anifeedsci.2007.12.008

STOBBS, T. H. The effects of plant structure on the intake of tropical pastures. I. Variation in the bite size of grazing cattle. Australian Journal of Agricultural Research, Victoria, v. 24, n. 6, p. 809-819, dec. 1973. https://doi.org/10.1071/AR9730809

TRABUE, S.; SCOGGIN, K.; TJANDRAKUSUMA, S.; RASMUSSEN, M. A.; REILLY, P. J. Ruminal fermentation of propylene glycol and glycerol. Journal of Agricultural and Food Chemistry, Easton, v. 55, n. 17, p. 7043-7051, jul. 2007. https://doi.org/10.1021/jf071076i 